\title{
Blood Conservation in Scoliosis Surgery
}

\section{Rajat Verma}

\begin{abstract}
Spinal deformity correction surgery can result in significant blood loss. Historically, large volumes of allogeneic blood transfusion were used in these patients. There is now an increasing awareness of the need to reduce allogeneic transfusion as there are reported adverse effects. Reducing blood loss during scoliosis surgery is a multipronged approach. This study reviews current strategies to reduce requirements for allogeneic blood transfusion for scoliosis corrective surgery.
\end{abstract}

Keywords: Blood loss, Blood salvage, Blood transfusion, Scoliosis, Spine surgery.

How to cite this article: Verma R. Blood Conservation in Scoliosis Surgery. J Postgrad Med Edu Res 2017;51(2):68-73.

\section{Source of support: Nil}

Conflict of interest: None

\section{INTRODUCTION}

Spinal deformity correction surgery can be associated with high levels of blood loss, necessitating increasing levels of blood transfusion. Blood loss can be related to patient factors, sex, Risser sign, preoperative Cobb angle, preoperative kyphosis magnitude, activated partial thromboplastin time level and fibrinogen level, and menstruation cycle phase or procedure-related variables..$^{1-5}$

Multisegmental surgery, bony osteotomy, length of surgery, and complex revision surgery can result in massive blood loss. ${ }^{6,7}$

Surgery for spinal deformity is associated with high levels of blood loss that may be increased with certain patient factors and complex or revision procedures that include osteotomies. ${ }^{1,8,9}$

The main risks/complications of blood transfusion fall into either infectious or noninfectious categories. Allogeneic transfusions are associated with an increased risk of surgical site and systemic infection, transmission of infectious agents, acute hemolytic reactions, and transfusion-related immune modulation. ${ }^{10-13}$ Moreover, both autologous and allogeneic transfusions contribute

\section{Consultant Spine Surgeon}

Department of Surgical Neurosciences, Salford Royal Hospital NHS Trust, Lancashire, UK

Corresponding Author: Rajat Verma, Consultant Spine Surgeon, Department of Surgical Neurosciences, Salford Royal Hospital NHS Trust, Lancashire, UK, Phone: +00447974129532 e-mail: backsurgeon@gmail.com to longer hospital stay and, consequently, increased hospital costs. ${ }^{14,15}$

Massive transfusions also put patients at risk of metabolic abnormalities, dilution of clotting factors, and hypothermia. ${ }^{16,17}$ Any intervention that can minimize the requirement for transfusion would have a significant beneficial effect on this patient cohort.

Exactly when is a blood transfusion necessary? The "absolute" threshold for red blood cell (RBC) transfusion is a controversial moving target, especially in the pediatric population, and the trend has been toward a lower absolute hemoglobin $(\mathrm{Hb})$ transfusion trigger over the years. In the adult population, for many years, anesthetists and intensivists often transfused to keep the $\mathrm{Hb}$ at or above 10 to $13 \mathrm{~g} / \mathrm{dL}$, based mainly on clinical experience.

More recently, the American Society of Anesthesiologists has recommended transfusing if the $\mathrm{Hb}$ is less than $6 \mathrm{~g} / \mathrm{dL}$, although they do not advocate a single transfusion trigger but rather assessment of the patient's comorbid conditions and current state. The American Association of Blood Banks advises using an $\mathrm{Hb}$ threshold of 7 to $8 \mathrm{~g} / \mathrm{dL}$ in stable hospitalized patients. Most recommendations for the pediatric population are based either on expert opinion or derived from adult studies, but as in the adult population, the trend has been toward tolerating lower $\mathrm{Hb}$ concentrations. ${ }^{18,19}$

\section{PREOPERATIVE}

Before surgery, routine preoperative laboratory tests, including prothrombin time (PT), partial thromboplastin time, international normalized ratio, and complete blood count, should be performed. Careful investigation of patient bleeding history or history of easy bruising is recommended. Hemoglobin and hematocrit levels should be reviewed before surgery. In patients where a low hemoglobin is identified before surgery, commencement of ferrous sulfate may help to improve levels before surgery. In orthopedic procedures overall, a hemoglobin level of less than $13 \mathrm{~g} / \mathrm{dL}$ has been associated with higher transfusion risk in orthopedic procedures. ${ }^{20}$

Patients with anemia were found to be more likely to have longer hospital stays, experience one or more complications, and suffer mortality within 30 days of surgery. ${ }^{21}$ Recent study has recommended setting a minimum preoperative $\mathrm{Hb}$ value that is $5 \mathrm{~g} / \mathrm{dL}$ higher than the transfusion trigger. Of 86 patients who underwent posterior instrumented fusion for adolescent 
idiopathic scoliosis (AIS), none required intraoperative allogeneic transfusion. Only 4 patients $(4.65 \%)$ received allogeneic transfusion, all within 2 days of surgery. ${ }^{19}$

\section{PREOPERATIVE AUTOLOGOUS BLOOD DONATION}

Preoperative autologous blood donation uses preoperative donations made by the patient in advance of surgery. ${ }^{22}$

The goal behind the use of autologous blood is to prepare blood for intraoperative or postoperative transfusion without the potential risk for blood-borne pathogens, blood type mismatch, or immunological adverse effects associated with allogeneic blood exposure.

The limitations to autologous blood donation before major spine surgery include the potential for preoperative anemia and an inability to obtain sufficient units of blood. ${ }^{23}$ In addition, autologous blood donation is not cost-effective if more than $15 \%$ of the donated blood must be discarded. ${ }^{24}$

The optimal strategy for timing preoperative donation, as well as the number and type of units is a matter of debate. Whole blood has the advantage of being the most physiologic. However, coagulation factors experience substantial degradation as early as 8 hours after donation.

If the donated blood is separated into red cells and fresh frozen plasma, the storage life becomes much longer. This does, however, require special processing and added cost.

\section{ERYTHROPOIETIN}

Erythropoietin is a hormone produced predominantly by the peritubular cells of the kidney that promotes maturation of proerythrocytes to reticulocytes and differentiation of circulating reticulocytes to mature RBCs.

The rationale behind preoperative administration of erythropoietin before surgery is to optimize preoperative hemoglobin and hematocrit levels to facilitate preoperative autologous blood donation or to enhance hematocrit at the start of surgery.

In a randomized, controlled trial, Shapiro et $\mathrm{al}^{25}$ showed that patients who received erythropoietin before preoperative autologous donation programs were more likely to be able to complete them, less likely to require allogeneic transfusion, and had shorter hospital stays compared with patients who did not receive erythropoietin.

The presumption behind its use is that increasing baseline hematocrit is likely to decrease the transfusion needs during and after surgery.

Patients who had preoperative hemoglobin values of 10 to $13 \mathrm{~g} / \mathrm{dL}$ who received erythropoietin 10 days before surgery until 4 days after surgery were less likely to require allogeneic blood than patients who had not received erythropoietin. ${ }^{26}$ Other authors have reported similar findings. ${ }^{27}$

Studies evaluating erythropoietin have acknowledged the theoretical risk of thromboembolic events, although none have found a statistical increase in rates of clinically significant events. ${ }^{20,26,27}$

A recent study examining the adverse effects related to erythropoietin use in spine surgery by Stowell et $\mathrm{al}^{28}$ found an increased rate of deep vein thrombosis in patients who had erythropoietin but no difference in other thromboembolic events. An additional hurdle is the associated cost of routine administration of intramuscular injections of erythropoietin.

\section{ANESTHETIC CONSIDERATIONS}

Gardner ${ }^{29}$ first reported the use of intraoperative hypotension in 1946. In 1974, McNeill et $\mathrm{al}^{30}$ reported a $40 \%$ decrease of intraoperative blood loss with the use of induced hypotension in scoliosis surgery.

Controlled hypotension can be used intraoperatively to limit blood loss. Decreasing mean arterial pressure leads to diminished blood flow to the surgical field, resulting in less blood loss over the course of surgery. ${ }^{31}$

Authors have reported similar findings using only moderate hypotension with mean arterial pressures of $80 \mathrm{~mm} \mathrm{Hg} .{ }^{32,33}$ Since then, mean arterial pressures as low as $60 \mathrm{~mm} \mathrm{Hg}$ have been reported without adverse sequelae. The use of induced hypotension has also been shown to independently decrease the need for blood transfusions by approximately $45 \%$ and to decrease operating time by $10 \%{ }^{34}$

While complications from hypotensive anesthesia have been described, they remain exceedingly rare in young, healthy patients who undergo major spinal surgery. ${ }^{30,32-40}$ However, there has been some concern over end-organ hypoperfusion that has been reported with this technique, including cardiac ischemia, renal failure, and blindness. ${ }^{41}$

Visual loss, particularly ischemic optic neuropathy, is one of the most concerning complications that may be associated with hypotension. ${ }^{38}$ Intraoperative hypotension must be used judiciously and may be an easy culprit for ischemic optic neuropathy in a lawsuit. However, to date, there remains no proven causation effect. This complication is exceedingly rare and is multifactorial in nature.

It is important to keep the patient warm and monitor the core temperature throughout the surgical procedure. Even early hypothermia can prolong PT and result in increasing blood loss. 


\section{INTRAOPERATIVE CELL SALVAGE}

Perioperative autologous cell salvage (i.e., cell saver) is an intraoperative autologous blood transfusion technique in which blood lost during surgery is collected, anticoagulated, and centrifuged to separate RBC from plasma contents and subsequently infused back to the patient.

In a retrospective case-control study by Bowen et $\mathrm{al}^{4}{ }^{42}$ pediatric patients undergoing posterior spinal fusion for idiopathic scoliosis were separated into two groups based on cell saver use. Intraoperative cell saver use was associated with decreased allogeneic transfusion in surgeries lasting over 6 hours and in cases of large intraoperative blood loss ( $>30 \%$ of total blood volume).

Currently, many authorities find intraoperative blood salvage to be an effective blood management technique, despite the relatively expensive device and technical expertise required to operate it. ${ }^{43}$

\section{ANTIFIBRINOLYTICS}

In normal hemostasis, platelet adhesion and activation spurs initiation of the coagulation cascade. The end result of this cascade is a fibrin clot. Subsequently, plasminmediated fibrinolysis occurs, causing dissolution of the fibrin clot. Antifibrinolytic agents, such as epsilonaminocaproic acid (EACA), tranexamic acid (TXA), and aprotinin interfere with plasmin-mediated fibrinolysis without serving any prothrombotic function. ${ }^{9}$

The TXA and EACA have been associated with decreased blood loss in spine surgery. ${ }^{44}$

The accepted dosing for TXA is $10 \mathrm{mg} / \mathrm{kg}$ as a loading dose, with $1 \mathrm{mg} / \mathrm{kg} /$ hour for maintenance until incision closure, while the dosing for EACA is $100 \mathrm{mg} / \mathrm{kg}$ as loading dose, with $10 \mathrm{mg} / \mathrm{kg} /$ hour for maintenance until incision closure. ${ }^{45}$ In the pediatric surgical literature, TXA doses as high as $100 \mathrm{mg} / \mathrm{kg}$ as a loading dose with $10 \mathrm{mg}$ / $\mathrm{kg} /$ hour maintenance have been explored. ${ }^{46}$ The ideal dose and duration of TXA for pediatric and adult scoliosis patients remains debated and is a direction for future study.

In a small, prospective, randomized, double-blinded study, Elwatidy et $\mathrm{al}^{47}$ showed that large prophylactic doses of TXA during spine surgery could reduce the blood loss by $49 \%$ and decrease transfusion needs by $80 \%$.

\section{ACUTE NORMOVOLEMIC HEMODILUTION}

Acute normovolemic hemodilution is thought to decrease allogeneic transfusion needs in patients with spine deformity. It works under the rationale that lowering the hematocrit, while maintaining volume status, reduces RBC losses during surgery. Although blood volume loss should not change, fewer RBCs for the same volume of blood are lost because of decreased RBC concentration in the blood.
In acute normovolemic hemodilution, the first step is to carefully remove whole blood from the patient, while simultaneously maintaining the patient's volume status by infusing crystalloid solution. The autologous blood is collected and saved. The patient then undergoes spine surgery in a hemodiluted state, minimizing RBC loss throughout the procedure. After or during the operation, the autologous blood collected at the beginning of the procedure is transfused back into the patient.

As an additional benefit, normovolemic hemodilution may induce a mild hypercoagulable state. ${ }^{31,48,49}$ This may help to control intraoperative blood losses as well.

The adverse effects of normovolemic hemodilution are not well reported in the literature. Theoretically, a major caveat to normovolemic hemodilution is to avoid lowering the hematocrit to compromise oxygen delivery to the tissues. ${ }^{50}$

Overall, normovolemic hemodilution has been shown to be moderately effective at reducing exposure to allogeneic blood products, with less than one-third of studies reporting any adverse events related to this method. ${ }^{51,52}$

\section{SURGICAL STRATEGIES}

One mainstay of orthopedic surgical practice is proper patient positioning. Relton and Hall ${ }^{53}$ reported a significant decrease in intraoperative inferior vena cava pressure secondary to use of the Relton-Hall frame. By leaving the abdomen free in the prone position, there is decreased inferior vena cava pressure and thus decreased venous plexus filling around the spinal cord. Theoretically, there is also decreased vertebral venous pressure and, consequently, reduced intraoperative blood loss from decreased bone bleeding.

Other strategies aimed at reducing intraoperative blood loss include electrocautery, meticulous wound packing, and hypotensive anesthesia.

The use of a bipolar sealer device during posterior spine fusion in AIS significantly lowers total perioperative blood loss and reduced the transfusion rate in half when compared with using conventional monopolar electrocautery alone. ${ }^{54}$

This device uses radiofrequency energy in combination with saline irrigation to cause coagulation and sealing of soft tissue and bone at a much lower temperature $\left(<100^{\circ} \mathrm{C}\right)$ than standard electrocautery. ${ }^{55,56}$

A dual attending surgeon strategy was shown to be superior to a single surgeon strategy in posterior selective thoracic fusion in Lenke 1 and 2 AIS patients and leads to a quicker operation, reduced intraoperative blood loss, reduced risk of allogeneic transfusion, reduced morphine requirement, and shorter hospital stay. ${ }^{57}$ 


\section{INTRAOPERATIVE HEMOSTASIS}

Intraoperative hemostasis plays an important role in controlling blood loss. A number of tools exist for surgeons, including topical thrombotic agents and bipolar sealers. Local topical thrombotic agents are numerous in number and are an area of constant development.

Typically, topical thrombotic agents combine a matrix for mechanical compression and hemostasis, such as collagen, gelatin, and foam-based materials. They are often combined with chemical hemostatics, such as thrombin. ${ }^{58}$

The use of these types of combination hemostatic agents has become helpful during surgery (e.g., FloSeal, Baxter International, Deerfield, Illinois).

Topical hemostatic agents are not without adverse effects. Plasma-derived bovine thrombin, for example, may lead to the development of autoantibodies and subsequent bleeding and thrombotic complications in the postoperative period.

Expansion of hemostatic agents can cause compression of neural elements when placed in the spinal canal. Foreign body reactions can occur with mechanical hemostatic agents that fail to reabsorb. ${ }^{31}$

Bone bleeding is often encountered in orthopedic surgery and can often be difficult to control. Bone wax is a nonabsorbable mixture of beeswax $(70 \%)$ and petroleum jelly $(30 \%)$ and can be used to control bleeding from the bone. ${ }^{59}$ Bone wax utilizes its physical properties to stop bleeding. However, bone wax also has been shown to inhibit osteogenesis, so its use should be judicious and avoided in the fusion bed if possible. ${ }^{59}$

\section{CONCLUSION}

Blood is a scarce human resource, and there is a persuasive economic argument against the overuse of blood, analogous to the overprescription of drugs. Responsibility for ordering blood or blood components and the decision to transfuse rest ultimately with the attending clinician.

The risks of blood transfusion in India are significant. Multiple transfusion recipients have high rates of human immunodeficiency virus, hepatitis B, and hepatitis C infection, ${ }^{60-62}$ and several prospective studies enumerate the risk of developing posttransfusion hepatitis. ${ }^{63,64}$ Saxena et a ${ }^{65}$ followed up 182 transfusion recipients, at a Delhi hospital, who received an average of 4 to 5 units of blood; $7.7 \%$ developed posttransfusion hepatitis. National Blood Policy in India aims to ensure easy accessibility and adequate supply of safe blood and blood components, available according to need. ${ }^{66}$ The annual approximate requirement of blood in India is estimated to be 12 million units. However, a World Health Organization report estimated a 3 million unit shortage. ${ }^{67}$
Utilizing all the various blood conserving strategies in patients undergoing surgery for spinal deformity correction will lower the requirement for allogeneic blood transfusion and help preserve blood stocks, thus avoiding potential complications of blood transfusion in this patient group.

\section{REFERENCES}

1. Ialenti MN, Lonner BS, Verma K, Dean L, Valdevit A, Errico T. Predicting operative blood loss during spinal fusion for adolescent idiopathic scoliosis. J Pediatr Orthop 2013 Jun;33(4): 372-376.

2. Marks M, Petcharaporn M, Betz RR, Clements D, Lenke L, Newton PO. Outcomes of surgical treatment in male versus female adolescent idiopathic scoliosis patients. Spine (Phila Pa 1976) 2007 Mar;32(5):544-549.

3. Yu X, Xiao H, Wang R, Huang Y. Prediction of massive blood loss in scoliosis surgery from preoperative variables. Spine (Phila Pa 1976) 2013 Feb;38(4):350-355.

4. Li C, Xie Y, Li Z, Yang M, Sun X, Jianping Fan J, Zhu HYX, Wang C, Ming Li M. Intraoperative blood loss in female patients with adolescent idiopathic scoliosis during different phases of the menstrual cycle. PLoS One 2014 Nov;9(11):e112499.

5. Li C, Yang M, Wang C, Fan J, Chen Z, Wei X, Zhang G, Bai Y, Zhu $X, X i e Y$, et al. Preoperative factors predicting intraoperative blood loss in female patients with adolescent idiopathic scoliosis. Medicine (Baltimore) 2015 Jan;94(1):e359.

6. Guay J, Haig M, Lortie L, Guertin MC, Poitras B. Predicting blood loss in surgery for idiopathic scoliosis. Can J Anaesth 1994 Sep;41(9):775-781.

7. Doi T, Harimaya K, Matsumoto Y, Taniguchi H, Iwamoto Y. Peri-operative blood loss and extent of fused vertebrae in surgery for adolescent idiopathic scoliosis. Fukuoka Igaku Zasshi 2011 Jan;102(1):8-13.

8. Nuttall GA, Horlocker TT, Santrach PJ, Oliver WC Jr, Dekutoski MB, Bryant S. Predictors of blood transfusions in spinal instrumentation and fusion surgery. Spine. 2000 Mar;25(5):596-601.

9. Bess RS, Lenke LG. Blood loss minimisation and blood salvage techniques for complex spinal surgery. Neurosurg Clin North Am 2006 Jul;17(3):227-234.

10. Pull ter Gunne AF, Skolasky RL, Ross H, van Laarhoven CJ, Cohen DB. Influence of perioperative resuscitation status on postoperative spine surgery complications. Spine J 2010 Feb;10(2):129-135.

11. Triulzi DJ, Vanek K, Ryan DH, Blumberg N. A clinical and immunologic study of blood transfusion and postoperative bacterial infection in spinal surgery. Transfusion 1992 JulAug;32(6):517-524.

12. Ponnusamy KE, Kim TJ, Khanuja HS. Perioperative blood transfusions in orthopaedic surgery. J Bone Joint Surg Am 2014 Nov;96(21):1836-1844.

13. Innerhofer $P$, Klingler A, Klimmer C, Fries D, Nussbaumer W. Risk for postoperative infection after transfusion of white blood cell-filtered allogeneic or autologous blood components in orthopaedic patients undergoing primary arthroplasty. Transfusion 2005 Jan;45(1):103-110.

14. Shander A, Hofmann A, Gombotz H, Theusinger OM, Spahn DR. Estimating the cost of blood: past, present, and future directions. Best Pract Res Clin Anaesthesiol 2007 Jun;21(2):271-289. 
15. Seicean A, Alan N, Seicean S, Neuhauser D, Weil RJ. The effect of blood transfusion on short-term, perioperative outcomes in elective spine surgery. J Clin Neurosci 2014 Sep;21(9): 1579-1585.

16. Hardy JF, De Moerloose P, Samama M. Massive transfusion and coagulopathy: pathophysiology and implications for clinical management. Can J Anaesth 2004 Jan;51(4):293-310.

17. Shafi S, Kauder DR. Fluid resuscitation and blood replacement in patients with polytrauma. Clin Orthop Relat Res 2004 May;(422):37-42.

18. Verma RR, Williamson JB, Dashti H, Patel D, Oxborrow NJ. Homologous blood transfusion is not required in surgery for adolescent idiopathic scoliosis. J Bone Joint Surg Br 2006 Sep;88(9):1187-1191.

19. van Popta D, Stephenson J, Patel D, Verma R. The pattern of blood loss in adolescent idiopathic scoliosis. Spine J 2014 Dec;14(12):2938-2945.

20. Faris PM, Ritter MA, Abels RI. The effects of recombinant human erythropoietin on perioperative transfusion requirements in patients having a major orthopaedic operation. The American Erythropoietin Study Group. J Bone Joint Surg Am 1996 Jan;78(1):62-72.

21. Seicean A, Seicean S, Alan N, Schiltz NK, Rosenbaum BP, Jones PK, Kattan MW, Neuhauser D, Weil RJ. Pre-operative anaemia and peri-operative outcomes in patients who undergo elective spine surgery. Spine (Phila Pa 1976) 2013 Jul;38(15): 1331-1341.

22. Colomina MJ, Bago J, Pellise F, Godet C, Villanueba C. Preoperative erythropoietin in spine surgery. Eur Spine J 2004 Oct;13(Suppl 1):S40-S49.

23. Mercuriali F, Zanella A, Barosi G, Inghilleri G, Biffi E, Vinci A, Colotti MT. Use of erythropoietin to increase the volume of autologous blood donated by orthopaedic patients. Transfusion 1993 Jan;33(1):55-60.

24. Kleinert K, Theusinger OM, Nuernberg J, Werner CML. Alternative procedures for reducing allogeneic blood transfusion in elective orthopaedic surgery. HSS J 2010 Sep;6(2):190-198.

25. Shapiro GS, Boachie-Adjei O, Dhawlikar SH, Maier LS. The use of epoetin alfa in complex spine deformity surgery. Spine (Phila Pa 1976) 2002 Sep;27(18):2067-2071.

26. de Andrade JR, Jove M, Landon G, Frei D, Guilfoyle M, Young DC. Baseline haemoglobin as a predictor of risk of transfusion and response to epoetin alfa in orthopaedic surgery patients. Am J Orthop 1996 Aug;25(8):533-542.

27. Santoro JE, Eastlack RK, Mirocha JM, Bugbee WD. Impact of erythropoietin on allogenic blood exposure in orthopaedic surgery. Am J Orthop 2007;36(11):600-604.

28. Stowell CP, Jones SC, Enny C, Langholff W, Leitz G. An openlabel, randomised, parallel-group study of perioperative epoetin alfa versus standard of care for blood conservation in major elective spinal surgery: safety analysis. Spine (Phila Pa 1976) 2009 Nov;34(23):2479-2485.

29. Gardner WJ. The control of bleeding during operation by induced hypotension. J Am Med Assoc 1946 Nov;132(10): 572-574.

30. McNeill TW, DeWald RL, Kuo KN, Bennett ET, Salem MR. Controlled hypotensive anesthesia in scoliosis surgery. J Bone Joint Surg 1974 Sep;56(6):1167-1172.

31. Tse EY, Cheung WY, Ng KF, Luk KD. Reducing perioperative blood loss and allogeneic blood transfusion in patients undergoing major spine surgery. J Bone Joint Surg Am 2011 Jul;93(13):1268-1277.
32. Mandel RJ, Brown MD, McCollough NC 3rd, Pallares V, Varlotta R. Hypotensive anesthesia and autotransfusion in spinal surgery. Clin Orthop Relat Res 1981 Jan-Feb;154: 27-33.

33. Lawhon SM, Kahn AIII, Crawford AH, Brinker MS. Controlled hypotensive anesthesia during spinal surgery. A retrospective study. Spine (Phila Pa 1976) 1984 Jul-Aug;9(5):450-453.

34. Patel NJ, Patel BS, Paskin S, Laufer S. Induced moderate hypotensive anesthesia for spinal fusion and Harrington-rod instrumentation. J Bone Joint Surg 1985 Dec;67(9):1384-1387.

35. Hur SR, Huizenga BA, Major M. Acute normovolemic hemodilution combined with hypotensive anesthesia and other techniques to avoid homologous transfusion in spinal fusion surgery. Spine (Phila Pa 1976) 1992 Aug;17(8):867-873.

36. Paul JE, Ling E, Lalonde C, Thabane L. Deliberate hypotension in orthopedic surgery reduces blood loss and transfusion requirements: a meta-analysis of randomized controlled trials. Can J Anaes 2007 Oct;54(10):799-810.

37. Dutton RP. Controlled hypotension for spinal surgery. Eur Spine J 2004 Oct;13(Suppl 1):S66-S71.

38. Patil CG, Lad EM, Lad SP, Ho C, Boakye M. Visual loss after spine surgery: a population-based study. Spine (Phila Pa 1976) 2008 Jun;33(13):1491-1496.

39. Rylance PB, Carli F, McArthur SE, Ransford AO, Mansell MA The effect of induced hypotension and tissue trauma on renal function in scoliosis surgery. J Bone Joint Surg Br 1988 Jan;70(1):127-129.

40. Vitale MG,Moore DW, Matsumoto H, Emerson RG, Booker WA Gomez JA, Gallo EJ, Hyman JE, Roye DP Jr. Risk factors for spinal cord injury during surgery for spinal deformity. J Bone Joint Surg Am 2010 Jan;92(1):64-71.

41. Myers MA, Hamilton SR, Bogosian AJ, Smith CH, Wagner TA Visual loss as a complication of spine surgery. Spine (Phila Pa 1976) 1997 Jun;22(12):1325-1329.

42. Bowen RE, Gardner S, Scaduto AA, Eagan M, Beckstead J. Efficacy of intra- operative cell salvage systems in pediatric idiopathic scoliosis patients undergoing posterior spinal fusion with segmental spinal instrumentation. Spine (Phila Pa 1976) 2010 Jan;35(2):246-251.

43. Slagis SV, Benjamin JB, Volz RG, Giordano GF. Postoperative blood salvage in total hip and knee arthroplasty. A randomized controlled trial. J Bone Joint Surg 1991 Jul;73B(4):591-594.

44. Grant JA, Howard J, Luntley J, Harder J, Aleissa S, Parsons D. Perioperative blood transfusion requirements in pediatric scoliosis surgery: the efficacy of tranexamic acid. J Pediatr Orthop 2009 Apr-May;29(3):300-304.

45. Verma K, Errico TJ, Vaz KM, Lonner BS. A prospective, randomized, double-blinded single-site control study comparing blood loss prevention of tranexamic acid (TXA) to epsilon aminocaproic acid (EACA) for corrective spinal surgery. BMC Surg 2010 Apr;10:13.

46. Faraoni D, Goobie SM. The efficacy of antifibrinolytic drugs in children undergoing noncardiac surgery: a systematic review of the literature. Anesth Analg 2014 Mar;118(3):628-636.

47. Elwatidy S, Jamjoom Z, Elgamal E, Zakaria A, Turkistani A, El-Dawlatly A. Efficacy and safety of prophylactic large dose of tranexamic acid in spine surgery: a prospective, randomized, double-blind, placebo-controlled study. Spine (Phila Pa 1976) 2008 Nov;33(24):2577-2580.

48. Ng KF, Lam CC, Chan LC. In vivo effect of haemodilution with saline on coagulation: a randomized controlled trial. $\mathrm{Br}$ J Anaesth 2002 Apr;88(4):475-480. 
49. Ng KF, Lo JW. The development of hypercoagulability state, as measured by thrombelastography, associated with intraoperative surgical blood loss. Anaesth Intensive Care 1996 Feb;24(1):20-25.

50. Murray D. Acute normovolemic hemodilution. Eur Spine J 2004 Oct;13(Suppl 1):S72-S75.

51. Segal JB, Blasco-Colmenares E, Norris EJ, Guallar E. Preoperative acute normovolemic hemodilution: a meta-analysis. Transfusion 2004 May;44(5):632-644.

52. Bryson GL, Laupacis A, Wells GA. Does acute normovolemic hemodilution reduce perioperative allogeneic transfusion? A meta-analysis. The International Study of Perioperative Transfusion. Anesth Analg 1998 Jan;86(1):9-15.

53. Relton JES, Hall JE. An operation frame for spinal fusion. A new apparatus designed to reduce haemorrhage during operation. J Bone Joint Surg 1967 May;49B(2):327-332.

54. Gordon ZL, Son-Hing JP, Poe-Kochert C, Thompson GH. Bipolar sealer device reduces blood loss and transfusion requirements in posterior spinal fusion for adolescent idiopathic scoliosis. J Pediatr Orthop 2013 Oct-Nov;33(7):700-706.

55. Barsoum WK, Klika AK, Murray TG, Higuera C, Lee HH, Krebs VE. Prospective randomized evaluation of the need for blood transfusion during primary total hip arthroplasty with use of a bipolar sealer. J Bone Joint Surg Am 2011 Mar;93(6):513-518.

56. Marulanda GA, Ulrich SD, Seyler TM, Delanois RE, Mont MA. Reductions in blood loss with a bipolar sealer in total hip arthroplasty. Exp Rev Med Devices 2008 Mar;5(2):125-131.

57. Kwan MK, Chan CY. Does a dual attending surgeon strategy confer additional benefit for posterior selective thoracic fusion in Lenke 1 and 2 adolescent idiopathic scoliosis (AIS)? A prospective propensity matching score analysis. Spine J 2017 Feb;17(2):224-229.

58. Schonauer C, Tessitore E, Barbagallo G, Albanese V, Moraci A. The use of local agents: bone wax, gelatin, collagen, oxidized cellulose. Eur Spine J 2004 Oct;13(Suppl 1):S89-S96.
59. Renkens KL Jr, Payner TD, Leipzig TJ, Feuer H, Morone MA, Koers JM, Lawson KJ, Lentz R, Shuey H Jr, Conaway GL. A multicenter, prospective, randomized trial evaluating a new hemostatic agent for spinal surgery. Spine(Phila Pa 1976) 2001 Aug;26(15):1645-1650.

60. Kumar RM, Uduman S, Hamo IM, Morrison J, Khaurana AK. Incidence and clinical manifestations of HIV-1 infection in multitransfused thalassaemic Indian children. Trop Geogr Med 1994;46(3):163-166.

61. Aggarwal V, Prakash C, Yadav S, Chattopadhya D. Prevalence of transfusion associated infections in multitransfused children in relation to mandatory screening of HIV in donated blood. Southeast Asian J Trop Med Public Health 1997 Dec;28(4): 699-706.

62. Gosavi M.S, Shah SK, Shah SR, Pal RB, Saldanha JA, Banker DD. Prevalence of hepatitis $C$ virus (HCV) infection in Mumbai. Indian J Med Sci 1997 Oct;51(10):378-385.

63. Dasarathy S, Misra SC, Acharya SK, Irshad M, Joshi YK, Venugopal P, Tandon BN. Prospective controlled study of post-transfusion hepatitis after cardiac surgery in a large referral hospital in India. Liver 1992 Jul;12(3):116-120.

64. Saraswat S, Banerjee K, Chaudhury N, Mahant T, Khandekar P, Gupta RK, Naik S. Post-transfusion hepatitis type B following multiple transfusions of HBsAg-negative blood. J Hepatol 1996 Nov;25(5):639-643.

65. Saxena R, Thakur V, Sood B, Guptan RC, Gururaja S, Sarin SK. Transfusion-associated hepatitis in a tertiary referral hospital in India. A prospective study. Vox Sanguinis 1999; 77(1):6-10.

66. Ministry of Health and Family Welfare. An Action Plan for Blood Safety 2003. National AIDS Control Organization. India: Government of India; 2007.

67. Annual Reports 2007-08 to 2012-13. Department of AIDS Control, Ministry of Health and Family Welfare, Government of India. 